\section{Insurgency, crime, and agricultural labor expenditure: Evidence from Punjab, 1978-1990}

\section{Prakarsh Singh}

$\mathrm{M}$

uch evidence now exists on the adverse macroeconomic effects of violent conflict on economic output and growth. For example, a "typical" civil war is estimated to lead to around a 20 percent decline in household income and also to a reduction in economic growth of around 2 percent per year. In addition, a number of studies have computed estimates of the macroeconomic impact of terrorism on tourism, foreign direct investment, and growth. ${ }^{1}$ But in assessing the effects of violent conflict on economies there are problems associated with causal identification as it is possible for other factors, such as weak institutions, to lead to both violence and bad economic outcomes. ${ }^{2}$ Reverse causality from lower growth to violent conflict can then statistically bias the empirical estimates. This is one reason for the growth in the literature on understanding the effects of violence at the microeconomic level where the empirical biases are likely to be less severe and the transmission mechanisms can be better delineated. Micro-level evidence not only allows for "cleaner" estimates and heterogeneous effects to be explored but also may provide policymakers with sounder advice on how to cope with violence and to better anticipate the likelihood, duration, and channels of any adverse consequences that different forms of violence may take.

A companion article establishes evidence on the magnitude of the decline in long-term versus short-term agricultural investment in response to violent conflict in the Punjab. Defined as resulting in three or more deaths, a major insurgency event in a given district in a given year is statistically associated with reduced long-term fixed investment of close to 17 percent for an average farmer. Effects were far more muted for short-term investment. (Long-term fixed investment is represented by investment in wells and short-term investment by spending on fertilizers.) For 1981 to 1990, the insurgency's effects on investment resulted in an average farmer losing close to 4 percent of his annual income. Heterogeneous effects are found by income-level and farm location. ${ }^{3}$

In contrast, the present article focuses on farmers' labor-related decisions in the face of insurgent violence. Using micro-level farmstead expenditure surveys for the period 1981-1993, and focusing on the monetary amount spent by farmers on two types of hired labor, the main finding is that insurgency-related violence adversely affected farmstead spending on permanent, but not temporary, hiring, possibly not because of labor demand factors but because of labor supply shifts away from longerduration contracts. However, this effect appears to hold only for the richer half of the surveyed farm households.
The following sections briefly consider the literature this article contributes to and describe Punjab and the insurrection it experienced. Other sections then deal with the data, methods, and results, followed by a discussion as well as endnotes and references.

\section{Microeconomic studies}

Recent microeconomic studies of civil war have found adverse effects for cases ranging from Colombia to Burundi and Iraq. Often the focus is on education and health outcomes, that is, primarily public sectorrelated effects. Evidence on private sector-related effects, for example on investments by firms during and after violence, is more limited. In Colombia, for instance, fixed private investment assets have been found to decline, relative to mobile assets, in the case of guerilla warfare because they cannot be carried away in case of displacement due to war. Similarly, a study on Uganda finds that civil strife is correlated with lower investment and fewer nonagricultural enterprise startups. For either sector, the size of the estimates differs depending on the nature of the violence experienced, the type of investment, and the geographical location. A study on the effect of the Rwandan civil war on household welfare for instance found that violence reduced household consumption growth. ${ }^{4}$

Violence in the Punjab

Punjab is both a state in northeast India as well as a region extending much beyond the administrative borders of the state. Part of the region lies in today's Pakistan, the result of the partition of British India in 1947. In 1966, the Indian Punjab was further divided, along linguistic lines, of which the modern-day state of Punjab is one part. In 2011, its population numbered about 28 million people, with Punjabi-speaking Sikhs forming the majority in the rural areas and Hindus dominating the urban areas. For complex sets of reasons, a Sikh-led independence movement arose, the roots of which go back to the division of British India. The demand for a Sikh-dominated, Punjabi-speaking independent state, to be called Khalistan, were not granted by the government of India and eventually led to what is generally termed an "insurgency." Aimed at India's government and its representatives in the army and police, this lasted 


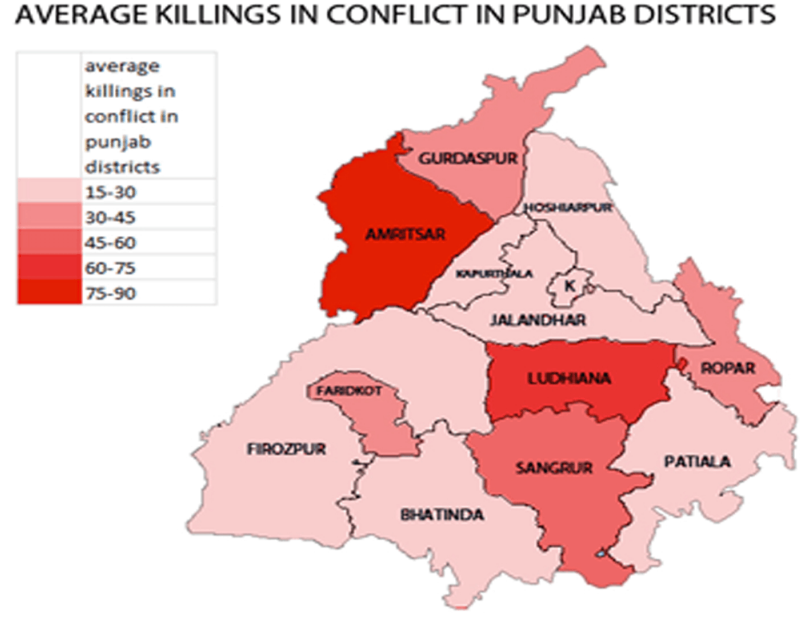

Figure 1: Average annual killings, Punjabi districts, 1981 and 1991, in major insurgency incidents.

Source: www.SATP.com.

from about 1981 to 1993 and is thought to have claimed over 20,000 lives. ${ }^{6}$ On average, the insurgents appear to have been moderately-well educated, coming from families owning small and medium-sized farmsteads. The movement ended with splintered insurgent groups being defeated by the state police.

P un ja b'

violent history is anomalous to some stylized facts of the civil war literature. For example, the literature points to a negative correlation between income and the likelihood of violence (that is, less income being associated with a higher probability of violence), and there is also cross-country evidence to suggest that "rough terrain" contributes to greater possibility of violence. But neither of these characteristics holds for Punjab. Prior to the violence, it had India's highest per capita GDP. Known as the bread-basket of India, Punjab is an extensive plain, sloping gently from the Himalayan mountains in the north to deserts in the south. Demarcated by the Indus and Yamuna rivers on its western and eastern borders, respectively, the land is rich, fertile, and flat. In one of several insightful interviews conducted by Joyce Pettigrew during the insurgency, a political leader told her: "If only we had had the mountains or the sea, we would have had our freedom by now ... the people are our jungle." 8

Having a rural base in Punjab was essential to the insurgents as this helped them remain hidden from police forces. This was despite not having forest cover or rugged terrain. Local knowledge allowed the rebels to credibly threaten retribution for informing the police. Kidnapping, or the threat thereof, was an efficient means used by insurgents to extract rents. Farmers were affected by the violence and were aware of attacks due to a high degree of local social capital. The companion article shows that between 1987/88 and 1992/93, Punjab's agricultural growth dropped from six percent to two percent due to a decline in long-term physical investment by farmers in response to increased violence in their districts. The mechanism applied by the insurgent movement was extortion. This instilled fear and, as will be shown in this article, led farming households to reduce spending on permanent manual labor with consequent declines in agricultural output. ${ }^{9}$

To analyze how the violence affected Punjab's economy, it is necessary to understand how it can work its way to influence business decisions. A likely mechanism is through the threat of extortion of employees (human capital losses) or through loss of property (physical capital losses). The threat of extortion may increase especially if the investment is visible to outside observers, such as insurgents. Pettigrew illustrates this in an interview with a farmer who stated: "If they were to demand a one- time payment that would be one thing. But people ask for payment regularly and not only that, several groups ask ... [T] hey assess how much we can pay by looking at the size of our house and our land holding." For instance, the threat of extortion may be higher if the farmer has a tractor or a well-equipped well. ${ }^{10}$ (Components of a well include screen and casing, a centrifugal pump, an electric motor, a diesel engine, galvanized pipes, hydrants, belts, and sprinklers. Each of these components would have an expected average service life of between 25 to 35 years, with annual maintenance costs of less than 2 percent of the initial investment. ${ }^{11}$ )

\section{Data and empirical analysis}

Three data sets are used in the analysis: annual insurgency-related killings and crime data, both at the district level, and annual farm expenditure survey data collected from representative farming households in each subdistrict. The data set on insurgents was obtained from the South Asia Terrorism Portal (SATP), a publicly available record of all major incidents, by district, in Punjab during the insurgency. ${ }^{12}$

The data on insurgency-related killings begins in 1981. They record 1,045 killings and 149 incidents with at least 3 killings. Figure 1 shows the average annual killings in major insurgent incidents in all districts of Punjab."Major insurgent incidents" are defined as incidents where at least three people died. Intense violence occurred in two districts bordering on Pakistan, Amritsar and Gurdaspur, and also in the central district of Ludhiana. The timing of the intensity was nonlinear across all districts. For instance, following peace pacts between moderate factions of the separatists and the Indian government, a lull in violence was seen in 1985 and in 1989. However, the extent of the nonlinearity differs across districts. These differences can be used to tease out the effect of violence at the district-level on farmers' labor spending. For example, for there to be a statistically significant effect of violence, labor spending in the year immediately after an event should be correlated with the district-specific nonlinearity. Moreover, if one does find a significant effect, one can then also delve into the channels behind the violence and see if they predict future crime.

To preview the results, Figure 2 shows that insurgent violence was accompanied by an increase in the lawlessness in the districts. Data on kidnappings and abductions (horizontal axis) is taken from an official dataset prepared by the Indian Crime Bureau. These are higher in the areas where insurgency-related killing was high as 


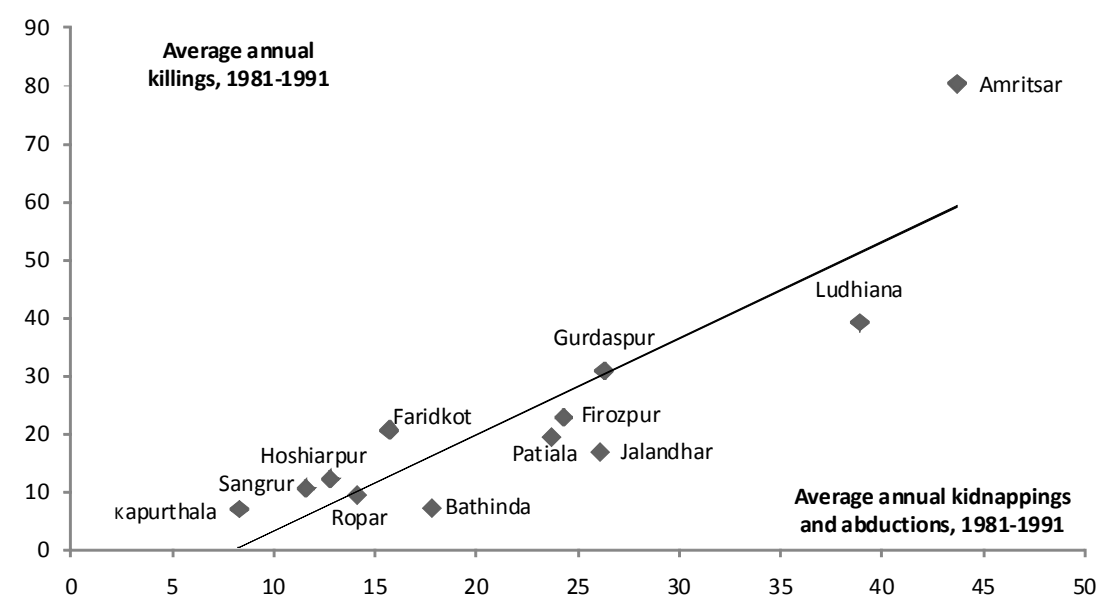

Figure 2: Average annual killings in major insurgency incidents and average annual kidnappings and abductions, 1981-1991.

Source: www.SATP.com and Crime Bureau, India.

well (vertical axis). The article returns to the topic of the relation between insurgencyrelated violence and other crime later on.

State-of-the-art microeconomic studies use difference-in-differences methodology. This relies on the assumption that violence-affected areas would have the same underlying trend in investment in capital and labor as peaceful areas if there was no violence. An alternative to using the difference-in-differences strategy where there are several time periods entails combining fixed regional effects and year-fixed effects: Whereas regional effects pick up institutional, geographical, and cultural factors that remain fixed for the entire duration of the period of violence, year effects are able to statistically control for time-varying macroeconomic effects such as inflation, trade, and agricultural innovation. By using individual-level data over time one can control for certain omitted political and economic factors that are either fixed in a district over time or are changing over the entire state in a similar fashion every year.

Repeated cross-sectional farm-level expenditure data from the Punjab Agricultural Department are used to isolate the effect, if any, of violence on farmers' spending on agricultural labor. One can also test for the effect of the insurgency on the number of people hired to try to isolate labor supply-side and labor demand-side channels. The farm-level data on labor spending was collected from annual surveys conducted by the Punjab Agricultural Surveys between 1978 and 1990. Readily available in the form of annual books, the main objective of the surveys of bullock-operated land holdings was to assess expenditure of the cultivators in the state and to analyze important changes that occurred in farming. The surveys cover the entire state of Punjab in a repeated cross-sectional approach. One bullock-operated holding per subdistrict was surveyed. These holdings have been selected taking into account the cooperation, willingness, and capability of the cultivator in maintaining day-to-day records of his farm.

The empirical specification is as follows:

(1) $\mathrm{LS}_{\mathrm{ijt}}=\alpha+\beta_{1}(\mathrm{INS})_{\mathrm{ijt}-1}+\beta_{2}(\mathrm{YFE})_{\mathrm{t}}+\beta_{3}(\mathrm{DFE})_{\mathrm{j}}+\beta_{4}(\mathrm{RAIN})_{\mathrm{ijt}}+\beta_{5}(\mathrm{HLC})_{\mathrm{ijt}}+\varepsilon_{\mathrm{ijt}}$,

where

- the $i, j$, and $t$ subscripts refer to household, district, and year, respectively.

- LS is the annual farming household expenditure on either permanent or casual labor, i.e., labor spending.

- INS is a dummy variable equal to 1 if a major (3+ killings) insurgent attack took place in that district, and 0 otherwise. ${ }^{13}$

- YFE (year-fixed effects) are dummy variables for each year following the onset of the insurgency.

- DFE (district-fixed effects) are dummy variables for each of the 12 districts in Punjab.

- RAIN is the level of rainfall recorded for each farming household in the dataset with the data (in millimeters) coming from the weather station nearest to the household.

- HLC (household-level controls) include (1) area held in hectares; (2) total number of family members; and (3) area under each quality of soil (either sandy, clay, sandy loam, or loam).

The coefficient of interest is $\beta_{1}$. After statistically controlling for year and district effects, and for rainfall and certain farm household-level factors, it measures the estimated effect of the insurgency on spending by farm households on either permanent or casual labor.

At least two concerns arise in estimating equation (1). First, a statistical bias may arise due to the selection of villages within subdistricts, farmers within these villages, and bullock-holding farmers in particular. This bias, if any, would act in the direction of showing a smaller than the likely true causal effect of insurgent violence. ${ }^{14}$ Thus, the reported estimates for labor spending due to violence (see below) are likely to be underestimates. Second, whereas the annual data on violence is compiled from January to December, the data from the agricultural surveys is recorded from July to June, resulting in a six-months data shift.

The two categories of labor spending are "permanent" and "casual" labor. Both refer to manual labor. "Permanent" means wages paid to labor hired for the entire year. If any family members were working on the farm, the relevant opportunity cost was added to the permanent labor spending variable on the basis of wages paid to 
Table 1: Summary statistics of mean labor expenditure and income by district

$\begin{array}{lcccc}\text { District } & \text { Obs. } & \text { (1) } & \text { (2) } & \text { (3) } \\ & & & & \\ \text { Amritsar } & 57 & 2,176 & 737 & 45,035 \\ \text { Bhatinda } & 43 & 2,129 & 641 & 62,786 \\ \text { Faridkot } & 37 & 1,791 & 915 & 45,980 \\ \text { Ferozepur } & 35 & 1,932 & 724 & 69,963 \\ \text { Gurdaspur } & 36 & 1,526 & 829 & 53,306 \\ \text { Hoshiarpur } & 48 & 1,545 & 507 & 29,921 \\ \text { Jalandhar } & 42 & 1,956 & 827 & 35,577 \\ \text { Kapurthala } & 31 & 2,362 & 776 & 39,243 \\ \text { Ludhiana } & 44 & 2,761 & 1,141 & 68,056 \\ \text { Patiala } & 57 & 2,225 & 662 & 51,920 \\ \text { Ropar } & 36 & 2,077 & 547 & 51,809 \\ \text { Sangrur } & 44 & 2,636 & 734 & 51,396\end{array}$

Notes: Columns (1), (2), and (3) are, respectively, the mean expenditure on permanent labor, mean expenditure on casual labor, and mean gross farm income for a farming household per year. The observations, average expenditure, and mean farm income are of all farming households surveyed from that district over the period 1978-1990. permanent hired labor in the village. "Casual" refers to wages paid to temporary labor hired during the year. Effects on both types of labor spending can be estimated. On average, of their total farm-related expenditure, farmers spend close to 20 percent on permanent labor and 7 percent on casual labor.

The estimate of the effect of violence on labor spending (that is, wages times the number of farm workers hired) may be either positive or negative. The estimate will be positive if there is an increase in expenditure associated with the violence. One can also test for an effect just on the total number of hired people. Thus, if there is an increase in expenditure without a corresponding

change in the number of hired people, this would imply that wages have increased Higher wages could result from an inward shift of the labor supply-curve (perhaps due to labor out-migration) and a consequent movement along a steep (inelastic) labor demand curve, leading to an insignificant decline in the quantity of labor hired.

Conversely, if the $\beta_{1}$ estimate of insurgent violence on labor spending is negative, this could be due to either one of two reasons. First, there is a movement along a relatively flat (elastic) labor-demand curve, reducing the number of hired people, and thus labor spending (the supply-side channel), or, second, that there is a shift in the demand curve of labor because of the complementary nature of labor with capital in the production function (the demand-side channel). ${ }^{15}$ Here, we need not necessarily see a change in the number of hired people, particularly if the supply curve is assumed to be steep.

Summary statistics on labor spending and farm income for each district are presented in Table 1. As mentioned, the observations stem from a survey of a representative household in each subdistrict for each of the twelve districts for twelve years. The mean expenditure on permanent and casual labor, respectively, are Rs. 2,104 and Rs. 748, with higher expenditure in richer districts (for example, Ludhiana) and lower expenditure in poorer districts (like Hoshiarpur).

Column 1 of Table 2 (on page 37 ) shows a statistically significant negative effect of insurgent violence on farm spending on permanent labor. Relative to baseline spending on permanent labor, the estimated coefficient of -249.5 reflects a decline of 11.4 percent. (This is similar in magnitude to the about 17 percent decline in spending on wells. ${ }^{16}$ ) Because the corresponding coefficient for casual labor (of 7.442) is not statistically different from zero, this finding suggests that there is no substitution of spending on permanent labor into spending on casual labor. Moreover, when splitting the sample between "rich" and "poor" farm households, the findings suggest that the effect of reduced spending on permanent labor is restricted to the richer households (minus 16 percent, relative to baseline spending.)

The reduction of spending on permanent labor (wages times labor hired) may occur because such labor is complementary with long-term investment such as wells As mentioned, however, spending reductions may also reflect a labor supply-side effect resulting from a decrease just in the number of overall hires. But a separate estimation, not shown here, does not find a statistically significant effect of violence on the total number of people hired (hired workers and family members working on farms) ${ }^{17}$ Moreover, an increase in the number of family members alone is associated statistically only with a reduction on casual labor spending by the poorer half of the farm households in the sample. Table 2 also shows that differences in the size of the land farmed, amount of rainfall, and soil type have essentially no (statistical) effect on labor hired.

In sum, adverse effects of spending on permanently labor hired by the richer farmsteads appear to stem solely from insurgent violence. The results with total quantity of labor used (hired labor plus family members) are not statistically significant (due to high standard errors) but are pointing toward a decrease in the quantity of labor used. Thus, while one cannot convincingly make the case for either a demand side or a supply side effect, there is weak (imprecise) evidence that it was a supply shift along an elastic demand curve, decreasing the number of hired labor.

So much for the main effect of insurgency-related violence on farm labor spending. But what is the channel by which this effect works? As suggested before, insurgent violence can signal an increase in future insecurity. To see this, Table 3 is a matrix of correlations of insurgent violence, crime, and future crime. For instance, the district-level correlation between the presence of insurgent violence and the number of robberies in the same year is 0.3728 . This is similar to the correlation with next year's robberies $(0.3982)$. For murders, too, the correlations are not very different (0.4347 and 0.4515). However, for kidnappings (and abductions), the correlation is close to five times higher in the following year as compared to the present year $(0.2257$ as against 0.0464$)$. This suggests that insurgent violence in one year may 
Table 2: Effect of insurgency violence on labor spending

\begin{tabular}{|c|c|c|c|c|c|c|}
\hline & $\begin{array}{l}\text { (1) } \\
\text { Perm. }\end{array}$ & $\begin{array}{l}\text { (2) } \\
\text { Perm. } \\
<\text { Med. }\end{array}$ & $\begin{array}{l}\text { (3) } \\
\text { Perm. } \\
>\text { Med. }\end{array}$ & $\begin{array}{l}\text { (4) } \\
\text { Casual }\end{array}$ & $\begin{array}{l}\text { (5) } \\
\text { Casual } \\
<\text { Med. }\end{array}$ & $\begin{array}{l}\text { (6) } \\
\text { Casual } \\
>\text { Med. }\end{array}$ \\
\hline Violence & $\begin{array}{l}-249.5 * \\
(118.7)\end{array}$ & $\begin{array}{l}-100.8 \\
(159.4)\end{array}$ & $\begin{array}{l}\mathbf{- 3 6 0 . 2 *} \\
(190.1)\end{array}$ & $\begin{array}{l}7.442 \\
(81.66)\end{array}$ & $\begin{array}{l}-73.84 \\
(47.66)\end{array}$ & $\begin{array}{l}106.2 \\
(144.2)\end{array}$ \\
\hline Area (hectares) & $\begin{array}{l}-52.08 \\
(37.04)\end{array}$ & $\begin{array}{l}-85.42 \\
(52.45)\end{array}$ & $\begin{array}{l}-21.13 \\
(64.71)\end{array}$ & $\begin{array}{l}-0.342 \\
(29.51)\end{array}$ & $\begin{array}{l}26.29 \\
(41.48)\end{array}$ & $\begin{array}{l}-37.39 \\
(24.72)\end{array}$ \\
\hline $\begin{array}{l}\text { Total number of } \\
\text { family members }\end{array}$ & $\begin{array}{l}-0.288 \\
(11.60)\end{array}$ & $\begin{array}{l}-9.602 \\
(14.34)\end{array}$ & $\begin{array}{l}15.65 \\
(25.96)\end{array}$ & $\begin{array}{l}-\mathbf{1 0 . 6 4 *} \\
(5.825)\end{array}$ & $\begin{array}{l}\mathbf{- 1 0 . 8 3 * *} \\
(4.999)\end{array}$ & $\begin{array}{l}-6.904 \\
(14.15)\end{array}$ \\
\hline $\begin{array}{l}\text { Net rainfall } \\
\text { (in } \mathrm{mn} \text { ) }\end{array}$ & $\begin{array}{l}-0.193 \\
(0.235)\end{array}$ & $\begin{array}{l}0.0677 \\
(0.263)\end{array}$ & $\begin{array}{l}-0.257 \\
(0.361)\end{array}$ & $\begin{array}{l}0.161 \\
(0.174)\end{array}$ & $\begin{array}{l}0.0835 \\
(0.0741)\end{array}$ & $\begin{array}{l}0.347 \\
(0.342)\end{array}$ \\
\hline Sandy & $\begin{array}{l}-27.34 \\
(40.42)\end{array}$ & $\begin{array}{l}-22.81 \\
(67.76)\end{array}$ & $\begin{array}{l}-24.28 \\
(64.62)\end{array}$ & $\begin{array}{l}30.56 \\
(44.46)\end{array}$ & $\begin{array}{l}-19.91 \\
(33.58)\end{array}$ & $\begin{array}{l}87.70 \\
(64.81)\end{array}$ \\
\hline Clay & $\begin{array}{l}36.17 \\
(61.87)\end{array}$ & $\begin{array}{l}86.31 \\
(110.3)\end{array}$ & $\begin{array}{l}-2.815 \\
(85.26)\end{array}$ & $\begin{array}{l}-46.82 \\
(32.62)\end{array}$ & $\begin{array}{l}-61.91 \\
(48.29)\end{array}$ & $\begin{array}{l}11.45 \\
(36.96)\end{array}$ \\
\hline Sandy loam & $\begin{array}{l}36.39 \\
(36.00)\end{array}$ & $\begin{array}{l}54.05 \\
(54.17)\end{array}$ & $\begin{array}{l}39.19 \\
(69.14)\end{array}$ & $\begin{array}{l}11.19 \\
(27.61)\end{array}$ & $\begin{array}{l}-23.84 \\
(38.12)\end{array}$ & $\begin{array}{l}45.02 \\
(30.44)\end{array}$ \\
\hline Loam & $\begin{array}{l}48.82 \\
(32.70)\end{array}$ & $\begin{array}{l}54.21 \\
(39.97)\end{array}$ & $\begin{array}{l}61.49 \\
(60.71)\end{array}$ & $\begin{array}{l}2.403 \\
(27.31)\end{array}$ & $\begin{array}{l}-26.25 \\
(35.88)\end{array}$ & $\begin{array}{l}\mathbf{5 3 . 6 3 *} \\
(27.98)\end{array}$ \\
\hline Obse & 510 & 304 & 206 & 510 & 304 & 206 \\
\hline R-squared & 0.318 & 0.397 & 0.387 & 0.381 & 0.532 & 0.426 \\
\hline
\end{tabular}

Notes: All results include year-fixed effects and district-fixed effects. "Perm." and "casual" are annual expenditure by representative farming households on permanent and casual labor. " $<$ Med." and " $>$ Med." refer to splitting the dataset into farm households with income less than the median or more than the median. (Median income is Rs. 50,124.) "Net rainfall" is recorded at the weather station nearest to the farming household. The remaining variables are soil types on which cultivation takes place. Robust standard errors, in parentheses, are clustered at the village-level.

Statistically significant effects, ${ }^{* * *} \mathrm{p}<0.01, * * \mathrm{p}<0.05, * \mathrm{p}<0.1$, are highlighted with bold type-face.
Table 3: Correlation matrix for insurgent violence, crime, and future crime

$\begin{array}{lllllllll} & & \text { INS } & R & F R & K & F K & M & F M \\ \text { INS Insurgency } & 1 & & & & & & & \\ \text { R Robbery } & 0.3728 & 1 & & & & & \\ \text { FR Future robbery } & 0.3982 & 0.8525 & 1 & & & & \\ \text { K Kidnapping } & 0.0464 & 0.2526 & 0.219 & 1 & & & \\ \text { FK Future kidnap. } & 0.2257 & 0.376 & 0.3644 & 0.4421 & 1 & & \\ \text { M Murder } & 0.4347 & 0.8703 & 0.7194 & 0.3171 & 0.4528 & 1 & \\ \text { FM Future murder } & 0.4515 & 0.8557 & 0.8444 & 0.2876 & 0.443 & 0.9238 & 1\end{array}$

Notes: Insurgency is a dummy variable equal to 1 if a major insurgent incident (3 deaths or more) took place in a district in a year. Robbery, kidnapping, and murder refer to the annual number of robberies, kidnappings, and murders in a district. The corresponding future crimes are the total crimes in that district in the following year. Insurgency data is from South Asian Terrorism Portal and the crime statistics are from the Crime Bureau, Government of India.

signal a coming increase in kidnappings and abductions. Signaling works in situations of high social capital, that is, information transmission from village to village.

The main result then is that permanent, but not casual, labor spending declines in response to insurgent violence. This is consistent with both demand- and supply-side mechanisms, although there is limited evidence for the supply-side channel prevailing (a negative but insignificant coefficient on hires and an increase in kidnappings in the following year).

Discussion and conclusion

The article reports on a study on how insurgent violence has affected certain laborrelated choices by farming households in rural Punjab, India. It finds that an increase in insurgent activity is linked with a decline on spending on permanent farm labor. It also finds an increase in kidnappings and abductions (and, presumably, subsequent extortions), suggesting that violence and extortionary crime were sequenced complements during the Punjab insurgency of the 1980s. One policy implication would be to call for stronger policing. In fact, the insurgency effectively ended in 1992 as the police force increased from 20,000 to 60,000 during the preceding 10 years. ${ }^{18}$ A second implication is that the police should have been more active in areas 
where there are richer farmers and also in the districts bordering Pakistan where the levels of insurgent violence were particularly high (Figure 1).

Another set of policy implications deals with the agricultural policy of the state. For a primarily agricultural state such as Punjab, there needs to be deft handling of how investment can be bolstered despite the prevailing fear. Indeed, this needs to go hand-in-hand with the security situation itself. Providing subsidies toward specific long-term agricultural equipment may serve to alleviate some of the short-run negative effects of violence. Similarly, farmers can be provided with income support to hire additional labor to increase agricultural output (and productivity). Income support alone is not likely to be sufficient unless supplemented by effective police as farmers would still be subject to extortion.

Yet there are at least two reasons why even improving police effectiveness and providing income support alone may still not be sufficient to increase overall welfare: inequality and environmental degradation. During the so-called Green Revolution, Punjab's agricultural productivity increased greatly. But the consequent increase in average incomes was associated with rising inequality. For example, a review of more than 300 studies published from 1970 to 1989 showed that 80 percent of those that studied distributional effects of the new technology found increases in both interfarm and interregional inequality. ${ }^{19}$

From this and the companion article, we learn that violence has had an adverse effect on both physical investment decisions as well as on permanent labor spending decisions. Together, these effects would seem to somewhat reduce the inequality that had been generated during the years of the Green Revolution. Indeed, richer farmers were more adversely affected by violence. They cut investment by more, and they reduced spending on permanent labor more than their relatively poorer counterparts.

Policymakers will need to decide how to weigh efficiency against inequality when they make decisions on, say, subsidizing agricultural inputs for richer farmers in response to violence. Similarly, considerations in regard to labor laws and minimum wages would push the policymaker who cares about efficiency toward making the labor market more flexible in response to violence. These may have distributional consequences that may be correlated with the persistence of violence. Further research will be needed to understand how inequality may have affected insurgent violence in Punjab in the 1980s.

The two main crops grown in Punjab are wheat and rice. As both are water intensive crops, massive ground water-based irrigation resulted in a depletion of the water table. According to recent estimates, the average water table in central Punjab is falling at the rate of $0.23 \mathrm{~cm} /$ year. While some parts of Punjab are witnessing a rise in the water table, resulting in rising salinity and water logging, farmers elsewhere are pumping out 45 percent more groundwater than is replenished by monsoon rains. Thus, although the time period is shifted, from a counterfactual point of view the rate of decline might have been even higher if investment in wells had not declined during the insurgency of the 1980s. Ironically, from an environmental perspective, a decline in investment in wells following violence and extortions may well be "better" than an unsustainable increase in such investments. Wise policy would take these factors into account when thinking about the overall effects of violence on investment and economic growth. ${ }^{20}$

To conclude, this article provides evidence for an 11.4 percent decline in spending on permanent labor but not on casual labor. It does so through the use of micro-level farmer expenditure surveys using district and year-fixed effects. Insurgency-related violence possibly signals an increase in future kidnappings and may incentivize labor away from working longer duration contracts. There is weak evidence for the labor supply-side channel, and also heterogeneity in the effects between richer and poorer farmsteads. Future work may try to further delineate the channels associated with the dichotomous result, trying to more fully understand labor demand and labor supply before, during, and after periods of extended violence.

Notes

Prakarsh Singh is Assistant Professor of Economics, Amherst College, Amherst, MA, USA. He may be reached at $<$ psingh@amherst.edu $>$. I am grateful to Oriana Bandiera, Tim Besley, and Gerard Padro for their guidance and to Meghna Sridhar for her fine research assistance.

1. Civil wars: See, e.g., Collier, Hoeffler, and Rohner (2009); Hoeffler and Reynal-Querol (2003); Abadie and Gardeazabal (2003). Tourism, etc.: See, e.g., Eckstein and Tsiddon (2004) for Israel; Enders and Sandler (1996) for Greece and Spain; Enders, et al. (1992).

2. For example, tropical geography and being land-locked may lead to both violence and lower growth (Sachs, 2005). Similarly with other, unobservable, factors that cannot be statistically controlled for and that might affect both violence and growth

3. See Singh (2012). Relatedly, Brück (2004) shows for Mozambique that wartime choices such as subsistence farming enhance welfare in the postwar period.

4. Public sector: See, e.g., Camacho (2008); Akresh and de Walque (2009); Bundervoet, et al. (2009); Guerrero-Serdán (2009); León (2009); Chamarbagwal and Moran (2011); Shemyakina (2011). Private sector: Dinar and Keck (1997); Deininger (2003); Grun (2008). Rwanda: Bundervoet and Verwimp (2008).

5. For simplicity, this article follows the locally established terminology and refers to the perpetrators of the violence as "insurgents" rather than as "terrorists" or another designation. 
6. A figure of 30,000 is often is used in political speeches. But www.SATP.com and Telford (2001) both refer to "over 20,000" (Telford, 2001).

7. Insurgent education and background: Puri, et al. (2008). State police: See, e.g., www.satp.org [accessed 1 June 2012].

8. Pettigrew (1995). On mountain people and "rough terrain," see Pickering (2011).

9. Retribution: This was found to be the case for a village-level analysis; Puri, et al. (2008). Social capital: Singh (2008). Agricultural growth: World Bank (2004). Mechanism: Singh (2012).

10. A study by Chandhoke and Priyadarshini (2005) analyzed Punjabi district-level data for 1980 to 1992 and did not find a negative correlation between violence and agricultural performance. But this was because the study failed to statistically control for state-wide trends before and during the violence. Yet such a statistical control is necessary because if there is a general, overall gain in productivity due to better technology, this can statistically "mask" any negative correlation between violence and agricultural growth.

\section{Michael, Khepar, and Sondhi (2008).}

12. See www.satp.org. For example, Srivastava (2009) and VandenEynde (2011) use SATP data for their analyses of terrorism trends and Naxalite violence, respectively.

13. The " -1 " in the subscripted term for INS refers to a time lag, in this case of 6 months' time, so that the equation captures the effect, if any, on labor spending by an insurgency attack occurring six months before.

\section{This potential concern is addressed in Singh (2012).}

15. The decline in labor spending (wages times numbers of workers) provides one possible mechanism for the decline in investment, but there may indeed be others. For example, if electricity or irrigation costs increased in response to violence, this may in turn reduce the marginal productivity of, and hence the demand, for workers.

\section{Singh (2012).}

17. Detailed regression table results with the number of hired people are available on request from the author.

18. The Tribune [India], 5 March, 1993.
19. Freebairn (1995).

20. Salinity and water-logging: Chandhoke and Priyadarshini (2005). Water-pumping and monsoon rains: Mazumdar (2011). On war and environment, generally, see, e.g., Brauer (2009).

\section{References}

Abadie, A. and J. Gardeazabal. 2003. "The Economic Costs of Conflict: A Case-Control Study for the Basque Country." American Economic Review. Vol. 93, No. 1, pp. 113-133.

Akresh, R. and D. de Walque. 2008. "Armed Conflict and Schooling: Evidence from the 1994 Rwandan Genocide.” IZA Discussion Paper No. 3516. http://ssrn.com/ abstract $=1139906$ [accessed 5 June 2012].

Besley, T., H. Mueller, and P. Singh. 2011. "Conflict and Investment.” Note prepared for the IGC Workshop on Fragile States. Oxford, U.K.: St Anne's College, Oxford University.

Brauer, J. 2009. War and Nature: The Environmental Consequences of War in a Globalized World. Lanham, MD: AltaMira Press.

Brück, T. 2004. "The Welfare Effects of Farm Household Activity Choices in Post-War Mozambique." HiCN Working Paper 04. Households in Conflict Network. http://www.hicn.org/papers/wp04.pdf [accessed 5 June 2012].

Bundervoet, T., P. Verwimp, and R. Akresh. 2009. "Health and Civil War in Rural Burundi." Journal of Human Resources. Vol. 44, No. 2, pp. 536-563.

Camacho, A. 2008. "Stress and Birth Weight: Evidence from Terrorist Attacks." American Economic Review. Vol. 98, No. 2, pp. 511-515.

Chamarbagwala, R. and H. Morán. 2011. "The Human Capital Consequences of Civil War: Evidence from Guatemala." Journal of Development Economics. Vol. 94, No. 1, pp. 41-61.

Chandhoke, N. and P. Priyadarshi. 2005. "Electoral Politics in Post-Conflict States: The Case of Punjab." Ace Project. URL: http://aceproject.org/ero-en/regions/asia/ IN/chandhoke.pdf/at_download/file [accessed 5 June 2012].

Collier, P. 2006. "Economic Causes of Civil Conflict and Their Implications for Policy." Oxford: Department of Economics, Oxford University. http://users.ox.ac.uk/ econpco/research/pdfs/EconomicCausesofCivilConflict-I mplicationsforPolicy.pdf [accessed 5 June 2012].

Collier, P., A. Hoeffler, and D. Rohner. 2009. "Beyond Greed and Grievance: Feasibility and Civil War." Oxford Economic Papers. Vol. 61, No. 1, pp. 1-27.

Deininger, K. 2003. "Causes and Consequences of Civil Strife: Micro-level Evidence from Uganda.” Oxford Economic Papers. Vol. 55, No. 4, pp. 579-606.

Dinar, A. and A. Keck. 1997. "Private Irrigation Investment in Colombia: Effects of Violence, Macroeconomic Policy, and Environmental Conditions." Agricultural 
Economics. Vol. 16, pp. 1-15.

Eckstein, Z. and D. Tsiddon. 2004. "Macroeconomic Consequences of Terror: Theory and the Case of Israel." Journal of Monetary Economics. Vol. 51, No. 5, pp. 971-1002.

Enders, W. and T. Sandler. 1996. “Terrorism and Foreign Direct Investment in Spain and Greece." Kyklos. Vol. 49, No. 3, pp. 331-352.

Enders, W., T. Sandler, and G.F. Parise. 1992. "An Econometric Analysis of the Impact of Terrorism on Tourism.” Kyklos. Vol. 45, No. 4, pp. 531-554.

Fielding, D. 2003. "Modelling Political Instability and Economic Performance: Israeli Investment during the Intifada." Economica. Vol. 70, No. 277, pp. 159-186.

Freebairn, D.K. 1995. "Did the Green Revolution Concentrate Incomes? A Quantitative Study of Research Reports.” World Development. Vol. 23, No. 2, pp. 265-279.

Grun, R. 2008. "Household Investment under Violence: The Colombian Case.” World Bank Policy Research. Working Paper 4713. Washington, D.C.: World Bank.

Guerrero-Serdán, G. 2009. "The Effects of the War in Iraq on Nutrition and Health: An Analysis Using Anthropometric Outcomes of Children.” World Bank Report. http://papers.ssrn.com/sol3/Delivery.cfm/SSRN_ID1362157_code1228036.pdf ?abstractid $=1359161 \&$ mirid $=1$ [accessed 5 June 2012].

Hoeffler, A. and M. Reynal-Querol. 2003. "Measuring the Cost of Conflict." Oxford University, Oxford, U.K. http://www.conflictrecovery.org/bin/2003_Hoeffler_ Reynal-Measuring the_Costs_of_Conflict.pdf [accessed 5 June 2012].

Kalyvas, S. 1999. "Wanton and Senseless? The Logic of Massacres in Algeria." Rationality and Society. Vol. 11, No. 3, pp. 243-285.

León, G. 2009. "Civil Conflict and Human Capital Accumulation: The Long Term Effects of Political Violence in Peru." BREAD Working Paper No. 245. Berkeley, CA: University of California, Berkeley. http://ipl.econ.duke.edu/bread/papers/ working/245.pdf [accessed 5 June 2012].

Mazumdar, S. 2011. “Arid Land, Thirsty Crops.” Scientific American. Vol. 304, p. 26. Michael, A., S. Khepar, and S. Sondhi. 2008. Water Wells and Pumps. New Delhi: Tata Mc-Graw Hill.

Pettigrew , J. 1995. The Sikhs of the Punjab: Unheard Voices of State and Guerrilla Violence. London: Zed Books.

Pickering, S. 2011. "Determinism in the Mountains: The Ongoing Belief in the Bellicosity of "Mountain People." The Economics of Peace and Security Journal. Vol. 6, No. 2, pp. 21-25.

Puri, H.K., J.S. Sekhon, and P.S. Judge. 2008. Terrorism in Punjab: Understanding Grassroots Reality. New Delhi: HarAnand Publications.

Sachs, J.D. 2006. The End of Poverty. New York: Penguin Group.

Shemyakina, O. 2011. "The Effect of Armed Conflict on Accumulation of Schooling: Results from Tajikistan.” Journal of Development Economics. Vol. 95, No. 2, pp 186-200.
Singh, P. 2008. "Causes and Consequences of Terrorism in Punjab." Institute for Defence Studies and Analyses. http://www.idsa.in/idsastrategiccomments/ CausesandconsequencesofTerrorisminPunjab_PSingh_180708 [accessed 20 February 2012].

Singh, P. 2012. "Impact of Terrorism on Investment Decisions: Evidence from the Punjab Insurgency." Journal of Conflict Resolution. Forthcoming.

Srivastava, D. 2009. “Terrorism and Armed Violence in India.” IPCS Special Report, 71. http://www.ipcs.org/pdf_file/issue/SR71-Final.pdf [accessed 5 June 2012].

Telford, H. 2001. "Counter-Insurgency in India: Observations from Punjab and Kashmir." Journal of Conflict Studies. Vol. 21, No. 1. http://journals.hil.unb.ca/index.php/jcs/article/view/4293/4888 [accessed 5 June 2012].

VandenEynde, O. 2011. "Targets of Violence: Evidence from India's Naxalite Conflict." London: London School of Economics and Political Science. https://www.cemfi.es/ftp/pdf/papers/wshop/Targets_of_Violence.pdf [accessed 5 June 2012].

Verwimp, P. and T. Bundervoet. 2008. "Consumption Growth, Household Splits, and Civil War." Research Working Paper 9. Brighton: MICROCON. http://www.microconflict.eu/publications/RWP9_PV_TB.pdf [accessed 5 June 2012].

World Bank. 2004. "Resuming Punjab's Prosperity." Poverty Reduction and Economic Management Sector Unit, South Asia Region. Washington, D.C. World Bank. http://siteresources.worldbank.org/INTINDIA/Resources/ PunjabReport.pdf [accessed 5 June 2012]. 